\title{
PROPAGANDA POLÍTICA EN LOS PANEGÍRICOS POÉTICOS DE LOS REYES CATÓLICOS: UNA APROXIMACIÓN ${ }^{1}$
}

\author{
ANA ISABEL CARRASCO MANCHADO \\ Universidad Complutense de Madrid
}

\begin{abstract}
SUMARIO
1. Introducción.- 2. Los ámbitos de la propaganda.- 2.1. Propaganda y entradas reales.- 2.2. Propaganda y fiesta cortesana.- 2.3. Propaganda $y$ liturgia.- 2.4. Los infantes y la propaganda.- 2.5. Propaganda de guerra.3. Conclusiones.
\end{abstract}

\section{INTRODUCCIÓN}

A fines de la Edad Media se observa que aumentan los procesos de divulgación y popularización de las ideologías políticas, favorecidos por la aparición de la imprenta, pero también por la creciente complejidad que adquieren las manifestaciones externas o el aparato del que se reviste el poder, aparato mediante el cual se muestra a sus súbditos. Se trata de un proceso de comunicación entre el poder y sus gobernados que constituye la base de toda propaganda.

'Este trabajo ha sido realizado en el marco del proyecto de investigación Propaganda y legitimación en los orígenes de la Monarquía Hispánica (ca. 1400-ca. 1520): una visión multidisciplinar, perteneciente al programa de Proyectos Multidisciplinares de la Universidad Complutense de Madrid.

"Anuario de Estudios Medievales", 25 (1995) 
Afortunadamente, el concepto de propaganda política, aplicado a períodos históricos distintos al contemporáneo, ha dejado de ser considerado anacrónico, a juzgar por la historiografía que, ahora también en España, comienza a demostrar su interés por este tema².

Nuestro trabajo tiene como objetivo realizar una aproximación (no puede ser de otro modo, por el carácter de síntesis a que obliga la brevedad de espacio) a la utilización propagandística de los panegíricos poéticos dirigidos a los Reyes Católicos. El complejo reinado de los Reyes Católicos, durante el cual se afianzan las pretensiones de autoritarismo regio, al tiempo que se adoptan polémicas medidas de gobierno, precisa de una extensa investigación de los mecanismos de propaganda y su influencia en el ejercicio del poder.

El panegírico poético se vale del empleo de símbolos e imágenes que configuran una imagen regia sin contradicciones, un estereotipo del rey

\footnotetext{
-Algunos trabajos realizados para la Baja Edad Media inglesa y francesa: Peter Shervey LEwIS, War Propaganda and Historiography in Fifteenth Century France and England,

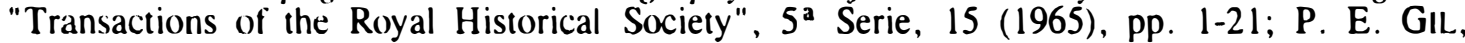
Politics and Propaganda in Fifteenth Century England: the polemical writings of sir $J$. Fortescue, "Speculum", 46 (1971), pp. 333-347; Claud GAUVARD, L'opinion publique aux conflicts des Etats et des principautes au début du XIVe siècle. "Principautés au Moyen Âge. Actes du Congrès de la Société des Historiens Médiévistes de l'Enseignement Supérieur Public", Burdeos, 1979, pp. 127-152; Claud GAUvaRD, Le roi de France et l'opinion publique à l'epoque de Charles VI en "Culture et idéologie dans la genèse de l'État Moderne", Roma, 1985, pp. 353-366; Nicole PONS, La propaganda de guerre française avant l'aparition de Jeanne d'Arc, "Journal des Savants", (1982), pp. 191-214. En la Península, ver, especialmente, los trabajos de José Manuel NIETO SORIA. Apología y propaganda de la realeza en los concioneros castellanos del siglo XV. Diseño literario de un modelo político, "En la España Medieval", 11 (1988), pp. 185-223; Les clercs du roi et les origenes de l'état moderne en Castille: propagande et legitimation (XIII èrne -XV ème siècles), "Journal of Medieval History", 18 (1992), pp. 297-318; Ceremonias de la realeza. Propaganda y legitimación en la Castilla Trastámara, Madrid, 1993. Se ha estudiado, sobre todo, la época Trastámara, desde sus inicios, hasta el último gobierno de Fernando el Católico: María RÁBADE ObRadó, Simbología y propaganda política en los formularios cancillerescos de Enrique II de Castilla, "En la España Medieval", 18 (1995), pp. 223-239; Emilio MITRE, La historiografía bajomedieval ante la revolución tratámara: propaganda política y moralismo, "Estudios de Historia Medieval en homenaje a Luis Suárez Fernández", Valladolid, 1991, pp. 333-347; Angust MaCKAY, Ritual and Propaganda in Fifteenth Century Castile, "Past and Present", 107 (1985), pp. 3-43; Luis Adao da FONSECA Una elegía inédita sobre la familia de Avís. Un aspecto de la propaganda política en la Península Ibérica a mediados del siglo XV. "Anuario de Estudios Medievales", 16 (1986) pp. 449-464; Alain Milhou, Propaganda mesiánica y opinión pública. Las reacciones de las ciudades de Castilla frente al proyecto fernandino de cruzada (1510-1511), "Homenaje a José Antonio Maravall", III, Madrid, 1985, pp. 51-62.
} 
fácilmente asimilable por el receptor ${ }^{3}$, lo que lo convierte en uno de los discursos privilegiados de la monarquía.

La dimensión propagandística de estos panegíricos se fundamenta en la oralidad intrínseca a toda composición poética, destinada a ser recitada o cantada. La poesía permite unas condiciones óptimas de divulgación de las ideas políticas, ya que no sólo se destina a un pequeño público, sino que, además, consigue llegar a un público amplio en el contexto de las celebraciones religiosas, cortesanas $\mathrm{y}$, sobre todo, ciudadanas, pues convocan a todo el pueblo en torno al monarca. De ahí que las ceremonias reales sean el ámbito ideal de proyección de la propaganda regia contenida en las composiciones poéticas escritas para exaltar la monarquía, la figura y acciones de los reyes ${ }^{4}$.

La puesta en escena de muchos de estos poemas, fruto de la intención de revestir de espectacularidad las celebraciones en las que se difunden, es otra variable que favorece la proyección propagandística. La fuerte dramatización de la vida política a fines de la Edad Media hace que muchos de estos poemas sean susceptibles de ser representados, contribuyendo a reforzar la efectividad de los objetivos que persigue la propaganda.

Finalmente, también hay que contar con la divulgación escrita, gracias a la imprenta, no desaprovechada por la monarquía para propagar su ideología política. Muchos de estos panegíricos se "popularizan" mediante las diversas tiradas de pliegos sueltos ${ }^{5}$.

Así pues, los panegíricos, por sí solos o en conjunción con otros recursos, colaboran en el cumplimiento de los fines de la propaganda política durante el reinado de los Reyes Católicos. En una primera etapa, el objetivo de la propaganda es conseguir la adhesión del mayor número de partidarios para defender sus reivindicaciones al trono castellano. Según Azcona, la

\footnotetext{
${ }^{3}$ Las principales fórmulas y expresiones a partir de las cuales se realiza la apología de la monarquía en los cancioneros han sido estudiadas por José Manuel NiETo, Apología y propaganda, pp. 200-221. Vid. además su obra Fundamentos ideológicos del poder real en Castilla (siglos XIII-XVI), Madrid, 1988.

${ }^{4}$ Las relaciones entre ceremonias reales y propaganda se estudian en la obra de NIETO, Ceremonias de la realeza. Propaganda y legitimación.

${ }^{5}$ Algunos de los panegíricos que estudiamos se divulgaron en forma de pliegos sueltos: los anónimos Coplas fechas a los altos estados de los reyes y Coplas fechas sobre el casamiento de la hija de la Reina de España; la obra Crianza y virtuosa doctrina de Pedro de Gracia Dei y las Trobas de la gloriosa pasión del Comendador Román. Vid, Víctor INFANTES, Edición, literatura y realeza, apuntes sobre los pliegos poéticos incunables, "Literatura Hispánica, Reyes Católicos y Descubrimiento", Barcelona, 1989, pp. 95-97.
} 
guerra de sucesión no fue sólo una guerra armada, sino que fue también una guerra contra la impopularidad ${ }^{6}$. Al mismo tiempo, la propaganda es empleada por los reyes para legitimar su acceso al poder $y$, una vez pacificado el reino, les ayuda, además, a consolidarse en él mediante la apología de la idea monárquica. El uso de la propaganda también les permite obtener apoyo y justificar sus proyectos de expansión territorial y de conquista, así como llevar a cabo reformas y polémicas acciones de gobierno. Hay que resaltar la elaboración de toda la propaganda de guerra que acompañó a la conquista del reino de Granada. Por último, no hay que despreciar el papel que pudo desempeñar la propaganda en el fortalecimiento de los lazos y relaciones políticas con los distintos cuerpos del reino, entre ellos, la nobleza.

\section{LOS ÁMBITOS DE LA PROPAGANDA}

A continuación analizaremos la dimensión propagandística de algunos panegíricos y su relación con algunas ceremonias o celebraciones que crean el ámbito propicio para su divulgación, como son las entradas reales, las fiestas cortesanas, las ceremonias litúrgicas o las bodas reales, a las que se aludirá como ejemplo de la utilización política que se hace de la figura de los infantes y de las ceremonias en las que intervienen. Por último, hablaremos del ámbito más propicio al desarrollo y funcionamiento de todos los instrumentos de propaganda al servicio de los reyes: la guerra. Más que un ámbito concreto, la guerra constituye por sí sola un fin al que se encamina el empleo de los recursos propagandísticos, pues veremos que muchos de los panegíricos que se analizan en los distintos ámbitos ceremoniales antes reseñados tienen como transfondo alguna situación de guerra, como es la guerra de sucesión, o el conjunto de sucesos que trae aparejada la rivalidad con el vecino reino francés.

'Tarsicio de AzCona, Isabel la Católica. Estudio crítico de su vida y su reinado, Madrid, 1964 , p. 153. Este autor fue uno de los primeros en resaltar la importancia de las «batallas publicísticas» desarrolladas como arma de guerra en la lucha de Isabel por alcanzar el trono. 


\subsection{Propaganda y entradas reales}

Según Rosana de Andrés, las entradas reales reflejan más claramente el sentimiento monárquico que otras ceremonias, como las bodas reales, los funerales $o$ las propias coronaciones ${ }^{7}$. La razón puede buscarse en la necesidad que tiene el poder de conseguir formas de reconocimiento de su autoridad en aquellos sobre los que se ejerce dicha autoridad. La reunión de todos los grupos que componen la comunidad ciudadana para recibir solemnemente a su rey, constituye la plasmación del tópico político, muy repetido en la literatura de la época, del "amor al rey" ${ }^{8}$. Además, la entrada real transmite una imagen de cohesión del reino, imprescindible para alcanzar la idea de consenso político en esta época9.

Los poemas dedicados a los reyes, que serían recitados en el transcurso de la entrada real, ayudan a completar el carácter propagandístico que posee este tipo de ceremonia. El poeta se convierte en el portavoz autorizado del discurso de reconocimiento que el rey demanda a su pueblo $^{10}$. Pero el poema también resulta ser el medio ideal para transmitir otros objetivos políticos, como son los derivados de las pretensiones de dominación del rey.

Todo esto queda reflejado en la composición dirigida a Fernando con motivo de su entrada en Barcelona en $1473^{\prime \prime}$. Morel Fatio lo ha fechado en 1473 , siendo, tal vez, la realizada el 31 de mayo, primera "entrada real" en la ciudad del heredero de Aragón, o la de julio del mismo año, durante el trayecto de regreso a tierras castellanas ${ }^{12}$. La entrada tendría lugar justo

\footnotetext{
'Rosana DE ANDRÉs, Las rentradas reales" castellanas en los siglos XIV y XV, según las crónicas de la época, "En la España Medieval", 4 (1984), p. 47.

${ }^{8}$ Sobre el tópico del amor-temor al rey, vid. Jose Luis Bermejo CaBRERO, Amor y temor al rey. Evolución histórica de un tópico político, "Revista de Estudios Políticos", (1973), 107 127.

${ }^{9}$ La relación entre la idea de consenso y opinión pública ha sido estudiada por GAUVARD en Le roi de France et l'opinion publique.

${ }^{10}$ Pierre BouRdieU, Language and symbolic power, Oxford, 1992, p. 113.

"Editada, a partir del ms. Esp. 305 de la Biblioteca Nacional de París, por Alfred MOREL FATIO, Souhaits de bienvenue adressés à Ferdinand le Catholique par un poète barcelonais en 1473, "Romania", XI (1882), pp. 333-356.

${ }^{12}$ Ibidem, p. 347. Menéndez Pidal, siguiendo la opinión de S. SANPERE Y MIQUEL, "Revista de Ciencias Históricas", IV, Barcelona, 1885, sostiene que el poema fue compuesto en junio de 1472, cuando Fernando acompañaba a su padre en el real de Pedralves; vid. La España de los Reyes Católicos (1476-1516), "Historia de España", XVII, vol. I, Madrid, 1989, pp. XCIXC.
} 
después de la reconciliación de Barcelona con su rey, en 1472. Fernando se dirigía a ayudar a su padre en el combate que mantenía con los franceses, que tenían sitiado Perpiñán. Este momento es especialmente significativo, pues conservamos otro poema que documenta la partida de Fernando de Castilla, y que indica que, con motivo de la despedida del príncipe, es posible que se llevara a cabo algún acto cargado de connotaciones políticas, con objeto de fortalecer el sentimiento de adhesión entre los partidarios de la causa de Isabel y Fernando. Se trata de una composición de uno de sus más fieles seguidores, Gómez Manrique, y en él se expresa el estado de ánimo general ante la marcha de Fernando en una situación tan difícil («Estamos como galea/ careçiente de patrón,/ como gente syn pendón/ e syn capitán varón/ en la dudosa pelean" ${ }^{13}$ ), razón por la cual se le anima a regresar cuanto antes para continuar su empresa.

Fernando llega a Barcelona, ciudad que acaba de salir de la revuelta $y$, por este motivo, en el poema de bienvenida se trata de agradar al futuro rey de Aragón con expresiones de amor y fidelidad: "Tan príncipe noble seays recebido,/ de todas las gentes amado y querido,/ mirado con oyos de rrey natural» ${ }^{14}$. A continuación, se plasma la apología del orden monárquico, que no es otro que el modelo religioso de monarquía, en el que el rey conserva la paz del reino guardando las leyes e impartiendo justicia, en contraste con el reino dividido: «Amando justicia, rey justificado,/ será prosperada la vuestra corona/...Con armas en guerra, en paç con las leyes/ se quieren los rreynos, Senyor, conservar;/ mas, iguay de la tierra do todos son rreyes,/ do todos presumen regir e mandar!/ Un Dios en el cielo, un rey en la tierra/ se deve por todas las gentes temer ${ }^{15}$. Barcelona aparece con la imagen de una mujer adúltera que será perdonada por su rey: «Que mucha clemencia t'esta preparada» ${ }^{16}$.

Las entradas reales, aunque organizadas por las autoridades ciudadanas, no escapan al control del rey, el verdadero protagonista y, por esta razón, no faltan expresiones que, además de exaltar y afirmar el poder monárquico, impulsan un determinado programa de expansión. En este poema se emplea el recurso a la profecía que sirve para alentar las

\footnotetext{
${ }^{13}$ Antonio Paz y Melia, Cancionero de Gómez Manrique, II, Madrid, 1885, pp. 161-162.

${ }^{14}$ A. Morel Fatio, ob. cit. p. 349.

${ }^{15}$ Ibidem, p. 351.

${ }^{16} \mathrm{Ibidem}$, p. 352.
} 
aspiraciones expansionistas de Fernando sobre la Península: «Que vos soys lexso vespertilion/ qu'estan esperando los rreynos d'Espanya ${ }^{17}$. Otra forma de lograr el mismo objetivo es saludar a Fernando con apelativos que le animan a alcanzar el máximo nivel de poder: «Aquell que del mundo s'espera monarcha" ${ }^{18}$, que es tanto como decir emperador universal ${ }^{19}$. Estas expresiones no son casuales, si tenemos en cuenta el contexto histórico en el que se pronuncian: imposición de la autoridad real sobre una ciudad sublevada, situación de lucha inminente contra el rival francés y disputa por el trono castellano.

\subsection{Propaganda y fiesta cortesana}

Gran parte de la vida cortesana se desarrolla en el marco de la fiesta. En esta época cada vez es más cierto el tópico de que la corte es un teatro y el rey es el actor protagonista. La música, las danzas y justas, los momos, convierten a la corte en un ámbito de representaciones en el que, gracias a los efectos plásticos del espectáculo, el poder expresa y transmite muchos de sus anhelos políticos.

Entre el ropaje alegórico y mitológico que recubre una composición poética de Pedro de Gracia Dei ${ }^{20}$, dirigida a Isabel cuando era infanta de Castilla, entrevemos uno de esos momentos en los que la corte es, por encima de todo, puro espectáculo. Se trata de la Crianza y virtuosa doctrina, un curioso poema de carácter alegórico donde, entre otras invenciones cortesanas, se describe la «dança y justa que se hizo en pronosticación de los

\footnotetext{
${ }^{17}$ Ibídem, p. 348. Sobre la imagen del "vespertilio", vid. Alain MiLhou, La Chauve-souris, le Nouveau David et la Roi Cache (trois images de l'empereur des derniers temps dans le monde ibérique: XIIIe-XVIIe s.), "Mélanges de la Casa de Velázquez", XVIII (1982), pp. 64-67.

${ }^{18} \mathrm{~A}$. MoRel Fatio, ob. cit., p. 348.

${ }^{19}$ Sobre la evolución del concepto de "monarquía", José Antonio MaRavall, El concepto de monarquia en la Edad Media española, "Estudios de Historia del Pensamiento Español", I, Madrid, 1983, pp. 67-83.

${ }^{20}$ Pedro Gracia Dei, al parecer, rey de armas de los Reyes Católicos y de Carlos V, fue cronista, heraldo e intérprete de los reyes. Vid. la introducción a la Relación de la vida del rey D. Pedro y su descendencia que es el linaje de los Castilla por Pedro Gracia Dei, ed. de Gregorio de ANDRÉS, "Cuadernos para la Investigación de la Literatura Hispánica", 18 (1993), pp. 233
} 
fados y buena fortuna de su Altezaw. La representación de los augurios del futuro reinado de los herederos al trono tal vez fuera un tema corriente en las fiestas cortesanas y no hay que perder de vista su intencionalidad propagandística. Algunos años antes, en el contexto de la guerra civil castellana, Isabel organiza para la mayoría de edad de su hermano Alfonso, unos momos que compuso Gómez Manrique, en los que participa la propia Isabel con otras damas de la nobleza partidaria de su causa. Disfrazadas de musas, recitan a Alfonso los augurios de su reinado, saludándole con apelativos reservados a los reyes, como es el de "rey e soberano señor ${ }^{22}$. Esta especie de juego profético que tiene lugar en el marco de la fiesta acentúa la legitimidad de los infantes como herederos al trono, pues son presentados como reyes que, con toda seguridad, gobernarán, y, además, lo harán siguiendo el modelo esperado de buen gobernante. No podemos fechar el texto con total exactitud, pues la única referencia clara es que Isabel es llamada «Doña Isabel primera, Infante de Castilla». No hay ninguna alusión a Fernando, por lo que, cabe pensar que el matrimonio aún no se hubiera producido. Un momento de exaltación equiparable al espíritu que refleja el poema debió reinar en el bando isabelino tras la concordia entre Isabel y el rey Enrique en Guisando.

En el poema de Gracia Dei, la figura de Isabel, el centro de la celebración, es elevada simbólicamente a una posición de magnificencia y triunfo. Toda la corte de Isabel acompaña a la infanta en un colorido desfile, trasunto de entrada real a una ciudad o, simplemente, festiva entrada al palacio. Podríamos imaginar que, en este desfile, al igual que en los momos dedicados años antes a su hermano, cada uno de sus partidarios representaría un papel en los «entremeses» e «invenciones» que tienen lugar a su paso ${ }^{23}$ y que forman parte de esta puesta en escena del triunfo de Isabel. Personajes alegóricos encarnan las virtudes que rodean a Isabel $y$, personificadas, recitan versos que exaltan su preeminencia y victoria, como los que "pregona» la Fama: «Esta es, esta la más principal,/ señora infante, persona

\footnotetext{
${ }^{21}$ El único ejemplar conocido se conserva en la Biblioteca Nacional de Madrid (I/12々2). Seguimos la edición de Antonio PAZ Y MELIA, Opúsculos literarios de los siglos XV a XVI, Sociedad de Bibliófilos Españoles, XXIX, Madrid, 1892, p. 381.

${ }^{22}$ Antonio Paz y MELIÁ, Cancionero de Gómez Manrique, II, p. 122. Existe una edición con adiciones escénicas en Fernando LÁzARo CARRETER, Teatro medieval, pp. 99-105.

${ }^{23}$ Pedro de Gracia DEI, ob. cit., p. 394.
} 
real/ de reynos y reys de grande riqueza,/ y a quien sola se da el alteza/ del carro y sylla muy más triunfal $»^{24}$.

El término que utiliza el autor para designar este desfile es "culto real» o, simplemente, «culto» ${ }^{25}$. Según el Diccionario Crítico Etimológico de Corominas, "culto" se refiere al culto religioso, que es la primera acepción que el vocablo tuvo en castellano. El Diccionario de Autoridades recoge "culto divino" y otros ejemplos que son posteriores a esta época. Así pues, "culto", aplicado al contexto de una celebración de signo pol'́tico, sacraliza dicha celebración transformándola en una especie de liturgia. El poeta parece consciente de esta asociación pues utiliza otras expresiones de resonancias religiosas. Cuando la procesión llega a la sala del palacio, donde sólo accede este "culto», la infanta se sienta en la parte más elevada de las gradas (no hay que perder de vista esta disposición simbólica del espacio) y, desde allí: "la miran llena de gracia,/ y ella mirándoles ansí se espacia:/ bendictos padres que tal merecieron,/...la gran magestad sagrada, real» ${ }^{26}$. Anuncia la imagen de Isabel entronizada en majestad.

Otras expresiones empleadas para calificar a Isabel denotan unas aspiraciones de poder claras, al tiempo que subrayan la legitimidad de la sucesión: Isabel es «vínculo, paz de regnos y reys, /...a quien las célicas leyes/ harán princesa, reyna, patrona». Las irregularidades en la sucesión al trono quedan así encubiertas por la decisión divina de otorgar el poder y la sucesión a Isabel. Ella es "leona", animal que simboliza la realeza, y su poder de mando como reina queda materializado en sus insignias reales: «el cetro de vuestra corona ${ }^{27}$.

Las reivindicaciones al trono se transforman, en virtud de la fiesta, en afirmación total de unas aspiraciones que se consideran ya logradas. El objetivo propagandístico de esta composición poética y de la fiesta que describe es hacer ver que el triunfo ya se ha producido, reforzando así la solidaridad en torno a Isabel, al tiempo que se acallan las dudas sobre la legitimidad de sus derechos al trono.

\footnotetext{
${ }^{24}$ Ibidem, p. 396.

${ }^{25}$ Ibidem, pp. 394 y 408.

${ }^{26}$ Ibidem, p. 408.

${ }^{27}$ Ibidem, pp. 381-382.
} 


\subsection{Propaganda y liturgia}

La ceremonia litúrgica ha sido definida como vehículo privilegiado de la propaganda política ${ }^{28}$. A los ojos del receptor, la ceremonia regia y la ceremonia religiosa, cargada intencionadamente de significación política, serán la misma cosa. En el discurso aparecen los mismos símbolos, las mismas metáforas encaminadas a conseguir los mismos fines: sumisión y reverencia. Jacques Le Goff ha afirmado que a los fieles de la religión real se les pide creer, no participar ${ }^{29}$; habría que añadir que, además, se les pide obedecer.

La liturgia, como ámbito de la propaganda política, añade el elemento de legitimación necesario en los momentos de crisis y, además, colabora con la propaganda de guerra, al ser el marco ideal en el que divulgar las concepciones del providencialismo político. Esto no sólo se manifestará de forma ostensible en la guerra de Granada, sino también en el contexto de otras guerras internas.

La guerra de sucesión al trono es el contexto en el que se compuso y divulgó el Sermón trobado al muy alto y muy poderoso príncipe, rey y señor, el rey don Fernando, rey de Castilla y de Aragón, sobre el yugo y coyundas que su alteza trahe por devisa, escrito por el predicador de los reyes Íñigo de Mendoza, y que Julio Rodríguez-Puértolas ha fechado en $1475-76^{30}$. Al ser un sermón rimado, en este caso, se combinan las posibilidades propagandísticas propias del sermón y las de las composiciones poéticas en general. Existe un mayor desarrollo argumentativo de las ideas, llegándose, incluso, a polemizar sobre diversos aspectos de la contrapropaganda regia que actuaba en ese momento. Además, la llamada a la acción que se intenta obtener del auditorio, está mucho más presente que en otras composiciones.

El Sermón de Íñigo de Mendoza desarrolla una alegoría simbólica en torno a la figura del yugo que aparecía en las armas de Fernando, valiéndose de unas palabras de San Mateo "Jugum meum suave est» (Mt 11, 30). Explicar el significado de esta divisa debió ser una necesidad, pues el

\footnotetext{
${ }^{28}$ Nieto Soria, Ceremonias, ob. cit., p. 84.

${ }^{29}$ Jacques LE GOFF, Aspects religieux et sacrés de la monarchie française du Xe au XIIIe sièle, "La royauté sacrée dans le monde chrétien", París, 1992, p. 28.

${ }^{30}$ Fray Ínigo de Mendoza. Cancionero, Madrid, 1986, p. LXVI. Este y otros poemas políticos del autor ya fue empleado por NIETO SORIA en Apología y propaganda.
} 
símbolo del yugo tenía unas connotaciones tremendamente negativas en la época, como puede verse en el fresco del Mal Gobierno pintado por Lorenzeti, en el cual aparece la figura del Tirano gobernando con el yugo en su mano. Fernando quería revestirse de una imagen de autoridad, pues se trataba de vencer en la guerra y sojuzgar a los nobles que se habían declarado sus enemigos, pero también necesitaba transmitir una imagen más benévola de su persona para apaciguar el temor que pudiera suscitar, y para inspirar mayor confianza en el pueblo castellano, que vería destacar sus buenas cualidades por encima de las del adversario portugués. Es un ejemplo claro de cómo el poder juega con una doble ideología, valiéndose de la ambigüedad que caracteriza la definición que suele hacer de sí mismo ${ }^{31}$ : por una parte emplea una ideología autoritaria y, por otra, una de limitación a dicha autoridad, límite que, viniendo del propio poder y no como una demanda de los gobernados, no tiene el objetivo real de moderar sus intenciones sino de afianzar las propias pretensiones de autoridad, gracias, precisamente, a esta utilización propagandística de la idea de límite. No sólo el yugo (símbolo de autoridad) con «melenas» (símbolo de la humanidad del rey) y "coyundas" (que simboliza para Mendoza la función regia de premiar y castigar) resume esta doble naturaleza del rey Fernando (naturaleza que, por otra parte, es la que propugnan los tratados doctrinales de la época), pues también se expresa mediante la metáfora del espejo: «Como en espejo doblado,/ príncipe muy poderoso,/ en una luna mirado/ haze el rostro mesurado/ y en la otra espantoso" 32 .

La idea de limitación se consigue marcando bien la diferencia entre el rey Fernando, revestido de todas las virtudes, y el tirano: «Rey temor de los tiranos ${ }^{33}$. Utiliza, además, la imagen arquetípica del reino de Dios, a cuyo gobierno el rey debe constantemente imitar ${ }^{34}$. También incorpora símbolos muy conocidos por ser utilizados en los tratados políticos de la época (ejemplo del grado de divulgación que estaba alcanzando la teoría

\footnotetext{
${ }^{31}$ Georges Balandier ha resaltado el carácter ambiguo que posee todo discurso político y el recurso a la polisemia para llegar a las diferentes audiencias; ver su obra El poder en escenas. De la representación del poder al poder de la representación. Barcelona, 1994, pp. 27-28.

${ }^{32}$ Íñigo de MENDOZA, ob. cit., p. 300.

${ }^{33}$ Ibidem, p. 303.

${ }^{34}$ Ibidem, p. 309.
} 
política). Se trata del símbolismo de las abejas, cuyo rey encarna la mansedumbre, pues no posee aguijón ${ }^{35}$.

A lo largo del sermón se subraya la legitimidad de la sucesión de Fernando: «nuestro natural señor/...a quien de derecho y razón/ vestieron ropa de estado/ de Castilla y de León/ $/{ }^{36}$. Otra forma muy efectiva de hacerlo (no olvidar este marco litúrgico de difusión) es aludir al origen divino del poder otorgado al rey: Dios pone en manos de Fernando la divisa o insignias del poder (coyundas y yugo) con el que sojuzgará a la noble$\mathrm{za}^{37}$. También se afirma la legitimidad sucesoria de los reyes haciendo clara alusión a hechos recientes, como es el matrimonio de Fernando e Isabel, para intentar desprestigiar los argumentos empleados por la propaganda del bando contrario: «por derecha subcesión/ vos vino la dignidad/...pues es de vuestro vando/ una verdad tan notoria/ cierta tenéis la victoria ${ }^{38}$. Prueba irrefutable de la legitimidad será el juicio de Dios favorable a los reyes, que otorgará la victoria final a Fernando ${ }^{39}$.

La propaganda de guerra se alimenta de referencias antifrancesas y antiportuguesas y de una crítica a la cooperación con estos de aquellos nobles enfrentados a los reyes: «atarlos, pues que son locos/ que os andan haciendo cocos./ Con nuestro falso metal/ hazen cocos, y con Francia,/ cócanvos con Portugal..." ${ }^{40}$. La utilización de la historia como propaganda de guerra se produce en dos niveles: por una parte, en el nivel de la historia cercana y, por otra parte, en el nivel de la historia remota o legendaria. Al primer nivel pertenece la alusión a la derrota castellana en Aljubarrota. Íñigo de Mendoza considera inaceptable que los nobles castellanos aliados de los portugueses hayan olvidado los muertos de aquella guerra. Durante la presente guerra, se intenta divulgar la idea de considerar la derrota de Aljubarrota como una cuenta pendiente que los reyes castellanos deben

\footnotetext{
${ }^{35}$ Ibidem, p. 310. Un resumen de la evolución de este símbolo político, en la obra de Jose Luis BERMEjo CABRERO, Máximas, principios y símbolos políticos, Madrid, 1986, p. 177-181.

${ }^{36}$ Ibídem, p. 299.

${ }^{37}$ Ibidem, p. 303.

${ }^{38}$ Ibidem, pp. 315-316.

${ }^{39} \mathrm{Ibidem}, \mathrm{p} .316$.

${ }^{40} \mathrm{Ibidem}$, p. 304.
} 
saldar $^{41}$. El nivel de la historia mítica lo ocupa la alusión a la perdición o destrucción de España en tiempos de don Rodrigo, tema en torno al cual surgieron diversas profecías sobre el rey, elegido por Dios, que habría de venir a restaurar aquella unidad perdida, expulsando a los musulmanes. Es uno de los temas de los que se nutre el mesianismo que se va creando en torno a los Reyes Católicos y que forma parte de su propaganda política ${ }^{42}$. Para Íñigo de Mendoza, al igual que para otros panegiristas, Fernando será el contramodelo de Rodrigo. Mendoza augura «no sólo ser subjuzgada/ a Castilla con Granada/ mas con poca fuerça y maña/ vos podéis ver rey de España " ${ }^{43}$. Resulta curioso que el poeta no se atreva aún a otorgar el título de "rey de España" o "reyes de España", pues, posteriormente, con mucha frecuencia Isabel y Fernando aparecerán nombrados así en los panegíricos. Por otra parte, cuando los reyes ya hayan asentado su poder, en tales panegíricos, las aspiraciones que siguen a la referencia granadina van dirigidas a la conquista de Jerusalén, y no a la de "España". Podría pensarse que, en el contexto de la guerra con Portugal, esto quiere decir que Fernando terminaría conquistando también el reino de Portugal, restituyendo, de este modo, la perdida unidad hispánica. Vemos así cómo la propaganda justifica las aspiraciones de dominio del rey Fernando sobre la Península.

Podemos seguir ilustrando los diversos aspectos de la colaboración entre liturgia y propaganda con otra obra que nos sitúa en el momento inmediato a la victoria sobre los portugueses: las Coplas de San Juan Evangelista $^{44}$ escritas por Ambrosio Montesino por encargo de la reina, cuya composición podría fecharse en torno a $1482^{45}$. Realmente se trata de un panegírico del santo, pero incorpora al final unas estrofas dirigidas a la reina en las que presenta a San Juan como su santo protector, pues se trata

\footnotetext{
${ }^{4 \mid}$ El ejemplo más significativo de utilización propagandística de la guerra que Juan I mantuvo por el trono portugués es la obra escrita por el Bachiller Palma para celebrar la victoria final de los Reyes Católicos y que tituló, de manera significativa, Divina retribución sobre la caída de España en tiempo del noble rey Don Juan el Primero, ed. de Jose María Escudero de la Peña, Madrid, 1879.

${ }^{42} \mathrm{La}$ utilización propagandística del mesianismo regio en época de los Reyes Católicos fue estudiada por Alain MiLhOU, Colón y su mentalidad Mesiánica, Valladolid, 1983.

${ }^{43}$ Íñigo de MENDOZA, ob. cit., p. 318.

${ }^{44}$ Editadas por Julio Rodríguez PuÉrtolas, Cancionero de Fray Ambrosio Montesino, Cuenca, 1987.

${ }^{45}$ Keith Whinnom, El origen de las comparaciones religiosas del Siglo de Oro: Mendoza, Montesino y Román, "Medieval and Renaissance Spanish Literature", Exeter, 1994, p.72.
} 
de una de las principales devociones de la reina ${ }^{46}$. El franciscano Montesino, predicador y confesor real, fue, junto con el también franciscano Íñigo de Mendoza, uno de los más fieles colaboradores de los reyes, divulgador de la propaganda regia desde la Capilla Real ${ }^{47}$.

Lo más interesante de estas coplas desde el punto de vista de la propaganda, es su forma de difusión, ya que están destinadas a ser cantadas, según se nos dice expresamente en el título, «al son de "Aquel pastorcico, madre que no viene $"{ }^{48}$, que parece una alegre y conocida canción popular de tema amoroso. Consideramos que este dato es de gran importancia para valorar la eficacia propagandística del poema. A un elemento conocido y agradable, como es esta canción, se le ha sobreimpresionado otro elemento desconocido, que es la imagen de la reina que se pretende inducir en el receptor. Después de haber escuchado esta nueva combinación, el oyente tendrá presente la imagen de la reina cada vez que vuelva a escuchar la canción «Aquel pastorcico», pues en su mente se ha creado una especie de reflejo condicionado ${ }^{49}$.

La imagen de Isabel transmitida en las coplas, en primer lugar se refiere al carácter de "reina cristianísima", a la que se alaba como fundadora de San Juan de los Reyes ${ }^{50}$, cuya construcción tuvo, por sí misma, un fin propagandístico, al ser edificado para celebrar la victoria sobre el rey portugués ${ }^{51}$.

\footnotetext{
${ }^{46}$ Entre las obras encargadas por la reina sobre San Juan Evangelista puede citarse la de Hernando de Talavera, Breve tratado más devoto y sotil de loores del bienaventurado sant Juan Evangelista, escrito en los primeros años del reinado. Fue editado por José Amador DE LOS Ríos, en "Historia crítica de la literatura española", VIİ, Madrid, 1969, pp. 544-561.

${ }^{47}$ Sobre el destacado papel de los "clérigos del rey" como agentes de la propaganda regia, véase José Manuel NIETO, Les clercs du roi.

${ }^{48}$ Ambrosio MONTESINO, ob. cit., p. 253.

${ }^{49} \mathrm{El}$ análisis de la música como soporte de la propaganda política podría dar sus frutos a partir del hecho de que, en tiempos de los Reyes Católicos, la música religiosa también se escribía sobre temas profanos y populares. En el siglo XVI esto ya no ocurre, según afirmó Higinio ANGlés, en La música en la Corte de los Reyes Católicos. I. Polifonía religiosa, Barcelona, 1960, p. 52. Resulta interesante comprobar que, en nuestros días, la propaganda publicitaria también recurre al mismo procedimiento que hemos descrito. En muchos anuncios televisivos se utilizan piezas de música clásica muy conocidas o canciones popularizadas durante los veranos anteriores para que sirvan de música a determinados mensajes publicitarios cantados.

${ }^{50}$ Ambrosio MONTESINO, ob. cit., p. 260 (los siguientes versos que se citen de este poema, se encuentran en esta misma página 260).

${ }^{51}$ Con su construcción, de algún modo, se quería buscar el contrapunto a la edificación del monasterio de Batalha, con la que se celebró el triunfo portugués en Aljubarrota. San Juan de los Reyes sellaba la legitimidad de Isabel como sucesora al trono. El templo llegó a ser llamado
} 
Encontramos expresiones que exaltan el poder de la reina, que pueden ponerse en conexión con el espíritu que se quería infundir en esta nueva etapa que inaugura la solución del problema de la sucesión y la pacificación del reino. Los panegiristas emplean ahora sin tapujos la fórmula "reina de España», al contrario de lo que parecía ocurrir en los años en los que Íñigo de Mendoza escribía su Sermón trobado. En los versos de Montesino, el orden de conquista que veíamos en la estrofa del Sermón analizada anteriormente se ha invertido, pues Isabel parece que ya "ha conquistado" España, puesto que Montesino se refiere a ella como "reina de España". Los deseos de conquista se dirigen ahora hacia Granada, horizonte más real para Isabel y Fernando en esta época que en la etapa anterior.

Otras expresiones que exaltan la superioridad regia y el poder de Isabel: "poderosa y muy más una/ que en las noches es la luna». Alguna expresión se acompaña de referencias gestuales, que indican la actitud que se debe mantener ante la persona real: "Así que con reverencia/ a vuestra alteza me inclino,/ temblando de la excelencia/ de su imperial presencia" ${ }^{52}$.

Por último, anotaremos brevemente otra forma de manifestarse la propaganda en la liturgia. Es sabido que Isabel y Fernando promovieron la traducción y elaboración de obras relacionadas con la vida de Cristo, entre las que no podía faltar las que recrean la Pasión y Resurrección. Se sabe que, durante las fiestas religiosas de Navidad, Pasión y Corpus, se organizaban representaciones dramático-religiosas. Aunque no se han conservado los textos, los documentos citan la presencia de «coplas e dichos» que, en opinión de Miguel Ángel Pérez Priego, estarían tomadas de otros textos literarios de diversa procedencia o serían encargadas directamente por la catedral ${ }^{53}$. No sería de extrañar que algunas de las coplas de tema religioso encargadas por los reyes hubieran sido difundidas de esta manera.

En este tipo de obras no faltan los panegíricos de los reyes que alaban su obra política y propagan la imagen de Isabel y Fernando como "reyes cristianísimos". Resulta de un gran interés la obra Coplas de la

en algún momento San Juan de la Reina; vid. Joaquín YARZa LuaCES, Los Reyes Católicos. Paisaje Artístico de una monarquía, Madrid, 1992, pp. 42-46.

${ }^{52}$ Los gestos son también un medio por el cual se expresa la propaganda regia. En la obra de Gracia Dei, anteriormente analizada, también se hace referencia a los gestos debidos a la reina: «y ally todos hazen reverencia/ no con cabeça, mas con rodilla»; vid. Pedro de GRACIA DEI, ob. cit., p. 408.

${ }^{53}$ Miguel Ángel PÉrez PrIEgo, Espectáculos y textos teatrales en Castilla a fines de la Edad Media, "Epos. Revista de Filología", 5 (1989), p. 145. 
Pasión con la Resurreçión de nuestro redentor Jesucristo, endereçadas a los muy altos, serenisimos y muy poderosos los reyes nuestros señores, hechas por el comendador Román su criado ${ }^{54}$. La «Entroduçión a los reyes» contiene diecinueve coplas de carácter panegírico a las que nos referiremos después al hablar de la propaganda de guerra. De esta obra resaltaremos un procedimiento de gran valor desde el punto de vista de la propaganda. En los momentos clave de la Pasión y de la Resurrección de Cristo, Román introduce unas plegarias y rogativas por los reyes dirigidas al Cristo sufriente, no sólo pidiendo protección, sino más poder para los monarcas ${ }^{55}$. Por una parte, los reyes intentan canalizar el fervor religioso y la veneración a Cristo en favor de ellos mismos y, por otra, pretenden mostrar que su creciente poder es el premio divino a la propia devoción de los reyes.

\subsection{Los infantes y la propaganda}

La importancia propagandística del papel desempeñado por los hijos de los Reyes Católicos, especialmente el príncipe Juan, ya fue apuntada por Tarsicio de Azcona, que afirmó que «la presencia del príncipe de Asturias fue una buena carta que jugó en muchas ocasiones la política de Isabel frente a sus pueblos ${ }^{56}$. Convendría seguir la pista a los actos, ceremonias, hechos relacionados con el príncipe Juan y, por supuesto, la abundante literatura que se le dedicó ${ }^{57}$. La figura del heredero se utiliza como medio de exaltación monárquica, al ser la prueba viviente de la continuidad $\mathrm{y}$, por tanto, de la perennidad de la institución. Sólo apuntaremos algunas notas sobre las bodas reales.

La doble boda del príncipe Juan y de la infanta Juana marca, quizás, el clímax político del reinado de los Reyes Católicos. Los acontecimientos nupciales fueron revestidos de una especial magnificencia. Hechos solemnes de este tipo no debían ser olvidados fácilmente, por lo que, no sólo las

\footnotetext{
${ }^{54}$ Editada por Giuseppe Mazzocchi, Firenze, 1990.

${ }^{55}$ Ibidem, pp. 120, 127, 135, 136 y 146. En una de estas plegarias dice: «dales poder soberano/ sin destino», p. 135.

${ }^{56}$ AzCONA, ob. cit., p. 501.

${ }^{57}$ Artículos recientes sobre este tema: Miguel Angel PÉREZ PRIEGO, Historia y literatura en torno al príncipe D. Juan. La «Representación sobre el poder del amor» de Juan del Encina», "Historias y Ficciones: Coloquio sobre la literatura del siglo XV", Valencia, 1992, pp. 337-349; J. SANZ HERMIDA, Literatura Consolatoria en torno a la muerte del príncipe Don Juan, "Studia Histórica. Historia Medieval", XI (1993), pp. 157-170.
} 
crónicas dejarán constancia escrita de ellos, sino también diversas composiciones poéticas casi contemporáneas a los hechos, y que tienen un afán divulgador mayor.

Las Coplas fechas a los altos estados de los reyes nuestros señores, escritas con motivo de la boda del príncipe Juan, recoge, exactamente, el momento en el que los reyes «salieron a misa con el alteza del muy alto príncipe e princesa de España e de los cavalleros que con sus altezas salieron" ${ }^{58}$. Los «altos estados de los reyes" no son otros que los «duq', es, grandes y señores/ de sus reynos ${ }^{59}$ y las coplas son, en realidad, una enumeración de los nobles que acompañaron a los reyes y príncipes en procesión hacia la iglesia, con una breve alusión a los vestidos, joyas y otras galas que traían para mostrar la importanca de su estado. Hay una alusión al arzobispo de Sevilla y a los embajadores de Venecia ${ }^{60}$, por lo demás, no se nombra a otros prelados ni a miembros de la comunidad ciudadana. Ciertamente se trata de un panegírico a los nobles. Este es, pues, un ejemplo claro de cómo actúa la propaganda para fortalecer las relaciones de los reyes con sus nobles ${ }^{61}$. A los miembros de la alta nobleza les interesa dejar constancia de sus nombres, no sólo en los hechos de armas de las guerras convocadas por los reyes, que aparecen recogidos en las crónicas, sino también en las ceremonias de afirmación monárquica, expresando su constante adhesión a la corona para obtener de ella posibles mercedes. La corona, por su parte, aprovecha esta actitud de la nobleza ante la boda del heredero al trono para transmitir al exterior una imagen de cohesión de las élites y de estabilidad del reino, al tiempo que se resalta la legitimidad de los hechos celebrados. Esto último lo vemos también reflejado, aunque de un

\footnotetext{
${ }^{58}$ Seguimos la reproducción facsímil hecha, a partir del único ejemplar que se conserva en la Biblioteca del Congreso de Washington, por Antonio PÉREZ GómEZ, en "Incunables poéticos castellanos", VI, Cieza, 1957. Al no estar paginado, daremos nuestra propia paginación. Sobre el recibimiento de la princesa Margarita se perdió un panegírico escrito por Hernando Vázquez de Tapia, Coplas al recibimiento de la princesa Margarita en Santander y Burgos, Sevilla, Ungut y Polono, 1497?.

${ }^{59}$ Ibidem, p. 3.

${ }^{60}$ Ibidem, pp. 5 y 8.

${ }^{61}$ Otro ejemplo de panegírico compuesto para estrechar los vínculos entre los miembros de la nobleza y los reyes, lo constituye el panegírico dirigido a la reina escrito en torno a 1481 por Diego de San Pedro e incluido en su obra Tratado de amores de Arnalte y Lucenda. En opinión de Keith Winnom el panegírico contribuyó a reconciliar al conde de Urueña, que había luchado en el bando de Juana durante la guerra, con la reina. Vid. su introducción a la edición de las Obras Completas, III, Madrid, 1976, p. 42.
} 
modo más completo, en otra composición poética que se hizo con motivo de otra boda real, la de la princesa Juana con el archiduque Felipe: las Coplas fechas sobre el casamiento de la hija del rey de España con el hijo del emperador $^{\mathrm{O}^{2}}$. El poema narra todos los acontecimientos festivos y solemnes que tuvieron lugar en la despedida de la infanta y el recibimiento que le hicieron a su llegada a Flandes. En este caso, el poema recoge la presencia en torno a los monarcas de los nobles, los prelados, los caballeros ciudadanos y comunidades, es decir, una representación de todo el reino asiste celebrando la fiesta del poder. De este modo, se realiza una perfecta puesta en escena de las jerarquías, las cuales ocupan cada una su lugar en el cuerpo social, el cual queda así transfigurado simbólicamente en el orden perfecto que debe regir el mundo, orden que es, en definitiva, sagrado: "Altos reyes poderosos/ por mano de Dios ungidos/ tan discretos, animosos, / justicieros, piadosos/ nunca vieron los naçidos" ${ }^{63}$. Los gobernados perciben la representación ideal del orden al que están sometidos.

La boda real es una alianza entre dos reinos, por lo que también se juega con los elementos de la propaganda para exaltar esas relaciones. En este caso se exalta la alianza con el Imperio: "Alli vi las dos naçiones/ con la su comunidad/ alemanes españoles/...porque hablando la verdad/ nunca vieron los humanos/tan rica solemnidad/ en la grande cristiandad/ no se acuerdan los romanos $n^{64}$. Esta alianza realiza la fraternidad exigida a los pueblos de la cristiandad, idea que se utiliza para desprestigiar al reino de Francia que, abordando las galeras que conducen a la infanta, se atreve a perturbar esa paz, atacando el orden instituido ${ }^{65}$.

\subsection{La propaganda de guerra}

La guerra pone en funcionamiento todos los instrumentos de propaganda al servicio de los reyes. Hemos visto que muchos de los panegíricos que hemos analizado en sus ámbitos ceremoniales se difunden en un contexto general de guerra. Al analizar el Sermón trobado de Íñigo de

\footnotetext{
${ }^{62}$ Seguimos la transcripción del impreso de Burgos, Friedrich Biel, c. 1496-7, realizada en "ADMYTE", 1, nº 61 .

${ }^{63} \mathrm{Ibidem}$, fol. $1 \mathrm{r}$.

${ }^{64} \mathrm{Ibidem}$, fol. $4 \mathrm{r}$.

${ }^{65}$ Ibidem, fol. $3 \mathrm{r}$.
} 
Mendoza hemos aludido a la utilización de la historia como arma propagandística, aspecto que, para el reinado de los Reyes Católicos, convendría ser investigado más profundamente. Pero en los panegíricos encontramos otros temas que salen a la luz en el contexto de las luchas armadas. La gierra de Granada creó sus propios temas, como es la divulgación de la idea de cruzada o guerra santa.

Alain Milhou ha hecho alusión a las ventajas políticas que comporta la idea de cruzada en el reinado de los Reyes Católicos ${ }^{66}$ : la más eviriente es la consecución del cobro del impuesto de cruzada, pero también la exaltación de la potencia de la monarquía frente a los grupos que todavía seguían siendo hostiles, así como la afirmación del liderazgo de la cristiandad por los reyes, frente al propio papa y a las pretensiones imperialistas de Carlos VIII de Francia. Existen dos obras poéticas, panegíricos de las acciones de los reyes contra el Islam, que contribuyen a divulgar la idea de guerra santa, junto con toda una trama ideológica fundamentada en el providencialismo: el Cancionero de Pedro Marcuello y la Consolatoria de Castilla, escrita por Juan Barba ${ }^{67}$.

La primera obra fue compuesta a lo largo de la guerra y recoge diversos materiales entregados a los reyes en varios momentos, en 1482 y en torno a 1488, a los que se añaden algunos otros escritos poco después de 1492 y en 1502, fecha de recopilación del cancionero para ser entregado a la princesa Juana ${ }^{68}$. Pedro Marcuello era alcaide de Calatorau, como él mismo dice en el Cancionero ${ }^{69}$.

Marcuello califica la guerra de Granada de «tan santa», sancta guerra», «muy justa», «sana», «santa querella», "sanctíssima conquista», "guerra prudente" $y$, "guerra del trino", expresión con la que se acentúa ese

\footnotetext{
${ }^{66}$ Colón y su mentalidad, ob. cit., p. 169.

${ }^{67}$ Pedro Marcuello, Cancionero, Zaragoza, 1987, edición de José Manuel Blecua a partir del único códice que se conserva y que se encuentra en el Museo Condé de Chantilly. La Consolatoria está edita en la obra de Pedro CÁTEDRA, La historiografía en verso en la época de los Reyes Católicos. Juan Barba y su Consolatoria de Castilla, Salamanca, 1989. Ambas obras incluyen, prácticamente, todos los tópicos empleados por la propaganda regia durante la guerra de Granada.

${ }^{68}$ María Carmen Marín Pina, Composición y cronología del Cancionero de Pedro Marcuello, "Archivo de Filología Aragonesa", XLIV-XLV (1990), pp. 161-176.

${ }^{69}$ Pedro Marcuello, ob. cit., p. 104. Su tío, Juan Cabrero, era camarero mayor del rey Fernando, vid. Manuel Serrano y SANZ, Noticias biográficas de Pedro Marcuello, "Boletín de la Real Academia Española", IV (1917), p. 26.
} 
carácter providencialista de guerra de Dios ${ }^{70}$. En una ocasión, Marcuello apela al papa para que colabore con el rey en la extinción del Islam ${ }^{71}$. De este modo, Fernando se convierte en líder de la cristiandad. De hecho, en más de un lugar se dice que Isabel y Fernando merecen ser emperadores; Isabel es una nueva emperatriz Santa Elena, pues conquistará Constantinopla y Santa Sofía será de nuevo iglesia ${ }^{72}$. Este afán imperialista es la lógica consecuencia de la aplicación a los Reyes Católicos de las concepciones mesiánicas, recurso que también hemos de analizar como parte de la propaganda de guerra.

Los objetivos económicos que se pretenden conseguir con la divulgación de la idea de guerra santa no pueden ser expresados con mayor descaro por Marcuello. No se refiere a la bula de cruzada, sino a los tributos que deben pagar todos los reinos, incluidos Sicilia y Cerdeña, para financiar la guerra, así como los bienes con los que deben contribuir las iglesias, sin olvidarse de los nobles ${ }^{73}$.

El acusado carácter providencialista que se desprende de esta obra casi es superado por el que aparece en la Consolatoria de Castilla. Esta obra elabora, mediante el verso, una visión historiográfica de la historia reciente de Castilla, desde la muerte de Álvaro de Luna y el nacimiento de Isabel hasta la conquista de Málaga, momento en el que se interrumpe la obra. El propio nacimiento de Isabel es considerado ya providencial. Castilla en ese tiempo vivía dominada por la bestia de siete cabezas Saligia, que simboliza los siete pecados capitales ${ }^{74}$. Desde el principio la obra está teñida de tintes apocalípticos. La primera parte de la obra es un alegato por la legítima

\footnotetext{
${ }^{70}$ Ver estas referencias en pp. $45,59,65,70,72,77,79,81,139,183,193,198,201,251$, 298 y 300 . En la p. 77 el propio Jesucristo habla en favor de los reyes ofreciéndoles su protección para que venzan en «la guerra santa mía». El agudo providencialismo que inspira la obra se basa, sobre todo, en el artificio de introducir a Cristo, la Virgen, numerosos santos (entre los que no pueden faltar Santiago ni San Jorge) y el propio Dios, contestando a las plegarias en favor de los reyes enviadas por la hija del autor. Otro recurso es incluir diversas oraciones como el Ave María, el Padre Nuestro, el Credo o la Salve Regina, glosadas con versos que exaltan la idea de cruzada. De nuevo encontramos la relación entre liturgia y propaganda y el propio autor nos da la clave de la difusión efectiva de estas plegarias en el ámbito de las celebraciones religiosas: «...recordar/ deviera el Ave trobada/ que se ofreció ante'el Pilar/ en tu capilla y altar/ por Marcuello presentadaw, ibidem, p. 308.
}

${ }^{71}$ Ibidem, p. 65.

${ }^{72}$ Ibidem, pp. 185, 301 y 308.

${ }^{73}$ Ibidem, pp. 39-40 y 118.

${ }^{74}$ La historiografia, ob. cit., p. 173. 
sucesión de los reyes y una deslegitimación de los derechos de Juana y de sus aliados portugueses. Esta guerra es campo de batalla donde luchan el Bien (Dios y los reyes) y el Mal (Lucifer y el rey portugués): «Sonó por la corte quel de Portogal/ rey se venía con grande quadrilla/ y que se metía por nuestra Castilla/ con yndevida causa de mal./ $Y$ todos contrastan aquell'entrada/ porque no trae razón ni justiçia/ syno Luçifer quel' da la codiçia/ d'agena corona tan bien eredada" ${ }^{75}$. Los enemigos de los reyes en esta guerra tienen una naturaleza diabólica, son «luçiferyanos» ${ }^{76}$. Parece implicar que esta guerra también es una guerra santa y, aunque Barba no la denomine así, resulta bastante atrevido, puesto que una guerra entre cristianos nunca es una guerra santa ${ }^{77}$. La victoria y el trono son, finalmente, otorgados por el juicio de Dios: «del todo les da su erençia/ el alto Juyzio tan bien heredada/ por ley y razón y por el espada/ dada por mano de la Providençia» ${ }^{78}$.

En el resto de la obra vemos que, si Lucifer ha luchado junto a los portugueses, que son cristianos, con más razón ayudará a los musulmanes del reino de Granada, a los que califica de «secta luçiferyna» ${ }^{79}$. En la narración de los sucesos de la guerra de Granada, prácticamente, no hay una estrofa en la que falte alguna referencia a Dios y a su intervención junto a los reyes. Dios les concedió el trono de Castilla para concluir la cruzada de Granada. Junto al rey luchan las milicias divinas formadas por ángeles ${ }^{80}$. La guerra sacraliza las personas de los reyes, que llevan camino de convertirse en $\operatorname{santos}^{81} \mathrm{y}$, cómo no, en los más poderosos de la cristiandad:

${ }^{75}$ Ibidem, p. 203.

${ }^{76}$ ibidem, p. 206.

${ }^{77}$ En la crónica de Pulgar pueden verse las diversas consideraciones sobre la guerra que tienen Fernando e Isabel: en un momento de la guerra de Granada Fernando quiere interrumpir la lucha para combatir a los franceses que tienen el Rosellón. Isabel dice que no puede dejar la lucha: «todas cosas pospuestas, debían ir al Andalucía en prosecución de la guerra de los moros. Porque decía ella que era tan justa e tan sancta empresa, que entre todos los príncipes cristianos no podía ser más honrada, ni que más dina fuese». Fernando, por su parte, piensa que «la guerra con los moros se podía por agora suspender puer era voluntaria e para ganar lo ageno», mientras que «la guerra con Francia no se debía escusar, pues era necesaria e para recobrar lo suyo. E que si aquella era guerra santa, estotra guerra era justa e muy conviniente a su honraw. Crónica de los Señores Reyes Católicos don Fernando y doña Isabel de Castilla y Aragón, "Biblioteca de Autores Españoles", LXX, Madrid, 1953, p. 400.

${ }^{78}$ Ibidem, p. 211.

${ }^{79}$ Ibidem, p. 326. Ver también pp. 320 y 322-323.

${ }^{80}$ Ibidem, p. 224.

${ }^{81}$ Ibidem, pp. 229-230, ver también p. 243 y 266. 
«llevan en todo tal condiçión/ para ser reyes del mundo mayores" ${ }^{82}$. Al igual que Marcuello, Barba hace un llamamiento al papa, al que pide que imponga la paz entre Fernando y el rey francés, pues sólo así podrá el rey continuar la guerra santa más allá de Granada ${ }^{83}$. Es la idea de "paz entre cristianos para luchar contra el Islam", idea con la que se intenta favorecer las condiciones para expandir la cruzada ${ }^{84}$.

La sacralización de los reyes y de su actuación en la guerra santa como "vicarios de Dios" (los reyes son, según Barba, los «presidentes» de Dios y el poder con el que gobiernan es «divino ${ }^{85}$ ), conlleva la sacralización de todo el orden social. Barba repite aquel verso que veíamos recogido en el poema barcelonés dirigido en 1473 a Fernando: «un Dios en el çielo, un rey en la tierra ${ }^{86}$ y exige del pueblo la adecuación y respuesta a este modelo teológico-político. Aquellos que no quieren luchar en la guerra santa, serán castigados por el rey y por Dios. Barba se refiere a los que siguen manteniendo las luchas de bandos y no acuden a Granada ${ }^{87}$. Esta alusión saca a la superficie uno de los objetivos de la guerra de Granada y de toda la propaganda creada en torno a ella: canalizar la conflictividad interna y ganar, definitivamente, la adhesión de toda la nobleza a los reyes, recurriendo a un fin común, la conquista de Granada, que pudiera aportar a todos grandes beneficios. Barba repite hasta la saciedad, de una u otra forma, la idea de que Dios hizo que Isabel y Fernando gobernaran en Castilla para llevar a cabo esta cruzada; resulta sospechosa esta insistencia que sería innecesaria si la política de los reyes tuviera plena aceptación en el reino.

Finalmente, analizaremos otro aspecto de la propaganda de guerra: el mesianismo regio y las profecías. El poder siempre remite a un pasado y/o a un porvenir ${ }^{88}$ y la profecía unifica de forma perfecta pasado y futuro, historia y propósitos futuros. Ya hemos hecho alguna alusión a la presencia de profecías en los panegíricos dirigidos a Isabel y Fernando, en torno a los

\footnotetext{
${ }^{82}$ Ibidem, p. 264.

${ }^{83}$ Ibidem, pp. 268-269.

${ }^{84}$ Un resumen de los planteamientos de José María Doussinague, Menéndez Pidal y Vicens Vives sobre la teoría de «paz entre cristianos contra el Islam» en, Alain MiLHOU, Colón y su mentalidad, ob. cit., p. 319.

${ }^{85}$ Ibidem, p. 299.

${ }^{86}$ Ibidem, p. 273.

${ }^{87}$ Ibidem, p. 275.

${ }^{88}$ Georges BALANDIER, ob. cit., p. 28.
} 
cuales se fue creando un halo mesiánico. Los reyes aprovecharon el clima apocalíptico que aún pervivía en la época, así como la herencia profética que había recaído desde hacía varios siglos en los reyes aragoneses ${ }^{89}$. Además, en la Península fructificó su propio ciclo profético, como consecuencia de la presencia musulmana, basado en la imitación de la historia judía: el pueblo elegido de Dios y castigado por sus pecados, pero redimido después mediante unos reyes escogidos.

Mesianismo regio y profecía hay que situarlos entre los más destacados medios de propaganda utilizados por los Reyes Católicos, tal y como ya demostró Alain Milhou, que dio la pauta para poder desarrollar un estudio más amplio sobre este tema ${ }^{90}$. Los reyes hicieron uso de ella durante la guerra de sucesión y, cómo no, en la guerra de Granada. Fue un arma de guerra empleada también por los reyes que aspiraban a la hegemonía en Europa: tanto Fernando el Católico como Carlos VIII de Francia se presentaban a sí mismos como el "Encubierto", el "Nuevo David" o el emperador de los últimos tiempos, con objeto de apoyar sus respectivas políticas de expansión en Italia. Milhou reunió los materiales que poseía y ofreció una lista con las profecías aplicadas a Fernando, que contenían, además, referencias a la conquista de Jerusalén y la atribución del título imperial $^{91}$. En primer lugar anotó la referencia que veíamos en el poema barcelonés de 1473. A estos materiales añadiremos otros aparecidos en los panegíricos poéticos que hemos estudiado.

-Profecías durante la guerra de sucesión:

Las Coplas al muy alto y muy poderoso príncipe, rey y señor el rey don Fernando de Castilla y de León y de Cecilia e Príncipe de Aragón, e a la muy esclarescida reina doña Isabel su muy amada muger, nuestros naturales señores, en que declara cómo por el advenimiento destos muy altos señores es reparada nuestra Castilla de Íñigo de Mendoza remiten al mito

\footnotetext{
${ }^{89}$ J. Guadalajara Medina, Las profecías del Anticristo en la Edad Media, Madrid, 1996. Eiximenis fue uno de los principales difusores de las profecías en la Corona aragonesa; vid el artículo de Pere BOHIGAS, Prediccions i profecies en les obres de fra Francesc Eiximenis, "Aportació a l'estudi de la literatura catalana", Barcelona, 1982, pp. 94-115.

${ }^{90}$ Colón y su mentalidad, pp. 349-403.

${ }^{91}$ Ibidem, pp. 391-394.
} 
de la destrucción de España. Se alude a las «altas profecías» de los reyes ${ }^{92}$ y se aplica a Fernando la profecía de Juan de Rocatallada, sin nombrarlo ${ }^{93}$. Los reyes deben tomar el título de emperadores ${ }^{94}$ pero, en esta primera época en la que se busca la preeminencia peninsular, este título posee unas connotaciones hispánicas, más que universales.

-Profecías durante la guerra de Granada:

En el Cancionero de Pedro Marcuello hay muchas referencias en general a la existencia de profecías, ${ }^{95}$ y alusiones a la profecía de la Sibila y de Isidoro, aplicada a la reina ${ }^{96}$. A lo largo de la obra se insiste en la conquista de Jerusalén, con alusiones también a Belén, la Casa Santa, el Calvario o Santa Sofia ${ }^{97}$. Ya hemos mencionado la existencia de atribuciones imperiales a los reyes.

En la Consolatoria de Castilla, de Juan Barba, no se alude a profecías concretas, pero sí a señales proféticas, augurios que vaticinan sucesos ocurridos posteriormente: la llegada desde Oriente de un cometa anuncia la llegada de Fernando desde tierras aragonesas y la conquista de Granada y de Portugal ${ }^{98}$; un terremoto que tuvo lugar en Sevilla y sólo afectó a la judería, es una premonición de la actuación de la Inquisición ${ }^{99}$. Hay una alusión indirecta a la conversión de los reyes en emperadores que también hemos citado y, aunque no se nombra Jerusalén, se habla de «pasar allende» $\mathrm{o}$ de continuar la conquistar por África ${ }^{100}$.

\footnotetext{
${ }^{92}$ Fray Íñigo de Mendoza, ob., cit., p. 33.

${ }^{93}$ «y el profeta, en conclusión,/ dize: "Rey, según venís,/ ¡cómo bramará el león/ y castigará el blasón/ la contraria flor de lis!». Ibidem, p. 36.
}

${ }^{94}$ Ibidem, p. 14.

${ }^{95}$ Pedro Marcuello, ob. cit., pp. 26, 29, 45, 51 y 68. La utilización propagandística de esta obra excede la coyuntura de la guerra de Granada, pues la recopilación se llevó a cabo en 1502.

${ }^{9}$ Ibídem, p. 87 y 111.

${ }^{97}$ Ibidem, pp. 26, 31, 41, 55, 77, 117, 145, 185, 253, 273, 285, 296 у 311.

${ }^{98}$ La historiografía, ob. cit., pp. 180-181 y 182-183.

${ }^{99}$ Ibidem, pp. 185-186. En los panegíricos también hay constancia de la propaganda antijudía (Pedro Marcuello, comendador Román, Guillén de Ávila), de la que no nos hemos ocupado, pero que también convendría ser investigada.

${ }^{100}$ Ibídem, pp. 265 y 269 , 
En las Coplas de la Pasión con la Resurrección, del Comendador Román, aparece el pronóstico de llegar a Jerusalén y conquistar el Santo Sepulcro $^{101}$. Fernando es «el encubierto», según la profecía atribuida por Román a San Isidoro ${ }^{102}$. Isabel, por su parte, es la "onça poderosa" y el "águila inglesa», así como Fernando es el «león» que aplastará la «flor de lis», según las profecías que Román atribuye a Crisóstomo y a Rocacisa (o Rocatallada $)^{103}$. Mito de la destrucción de España: Isabel y Fernando son los reyes que repararán el mal causado por Rodrigo ${ }^{104}$.

En una composición panegírica escrita antes de la conquista de Granada por un poeta del Cancionero General, Pedro de Cartagena se expresa el deseo de que Isabel conquiste Granada y, después, Jerusalén. Isabel es el contramodelo de Rodrigo y lleva el imperio inscrito en la inicial de su nombre ${ }^{105}$.

\section{-Profecías posteriores a la guerra de Granada:}

Un panegírico traducido del latín y glosado por un autor anónimo, por encargo de Gonzalo Chacón, alude a la conquista de tierras africanas en el trayecto hacia Jerusalén ${ }^{106}$.

Por último, el Panegírico a la reina doña Isabel escrito por Diego Guillén de Ávila, en 1499, desde Roma ${ }^{107}$. Como la Consolatoria, pertenece al género historiográfico, y recoge, al igual que esta otra obra, diversos augurios y señales proféticas en momentos clave de la guerra con Portugal,

\footnotetext{
${ }^{101}$ Comendador Román, ob., cit., p.92.

${ }^{102}$ Ibidem, p. 92.

${ }^{103}$ Ibídem, p. 93. Inmediatamente después se dice que Dios y los reyes sanarán «las enfermedades/ de las fístolas de Españan; creemos que no es casual que esto se diga justo después de hablar de la profecía que habla de aplastar la "flor de lis", símbolo de la sacralidad de la monarquía francesa. En la mente de Román está presente el poder taumatúrgico de los reyes franceses y esta es una manera de indicar que Isabel y Fernando tienen un poder sanador mayor, puesto que sanan la «fístolas» del reino y no las del cuerpo.

${ }^{104}$ ibídem, p. 94.

${ }^{105}$ Ver la composición de Cartagena en Brian DutTon, El Cancionero del siglo XV (c. 13601520), V, Salamanca, 1989-1990, p. 232.

${ }^{106}$ Alejandro AMARO, Una poesía inédita dr Fr. Ínigo de Mendoza, "Archivo Iberoamericano", X (1919), p. 130. Julio Rodríguez-Puértolas afirma que este poema no fue escrito por Mendoza, Fray Iñigo, ob. cit., p. LXV.

${ }^{107}$ Seguimos el facsímil editado por la Real Academia Española, Madrid, 1951. Al no estar paginado, seguiremos nuestra propia paginación.
} 
y en la guerra de Granada, vaticinando la victoria de los reyes ${ }^{108}$. De todos los panegíricos, es el que más datalla la conquista de todas las tierras que los reyes llevarán a cabo hasta alcanzar Jerusalén ${ }^{109}$.

\section{CONCLUSIONES}

Hemos intentado mostrar un breve panorama del aprovechamiento que estos textos poéticos ofrecen para el estudio de las formas de propaganda política en la corte de los Reyes Católicos. No sólo la naturaleza de estas composiciones hace del panegírico poético uno de los discursos propagandísticos más eficazes, sino también las características de los propios autores: los poetas no tienen inconveniente en decir lo que callan los cronistas. Exageran, "estiran" los argumentos y los llevan hasta sus últimas consecuencias. Los poetas son unos valiosos agentes de la propaganda regia.

\section{RÉSUMÉ}

Le panégyrique poétique et sa diffusion dans le cadre des célébrations et céremonies royales est un moyen privilégié pour divulguer la propagande des Rois Catholiques, Isabelle et Ferdinand, utilisés pour favoriser sa politique d'autoritarisme royale et d'expansion territorial. Dans cet article s'analise diverses compositions poétiques, de caractère panegyrique et son rapport avec la propagande politique et son contexte de divulgation (propagande et «entrée royale», propagande et fête de cour, liturgie et propagande, propagande et noces royales, et, pour finir, la propagande de guerre).

\section{SUMMARY}

The poetic panegyric and its diffusion in the context of the celebrations and royal ceremonies is a privileged way to spread the Catholic Kings (Isabella and Ferdinand)

\footnotetext{
${ }^{108}$ ibidem, pp. 17 y 23.

${ }^{109}$ ibídem, p. 32. En el momento en el que Guillén de Ávila escribía, otros reyes alimentaban sus sueños de cruzada hacia Jerusalén. En noviembre de ese mismo año de 1499 , Marsilio Ficino escribía un texto en honor de Carlos VIII en el que se le alienta a liberar Jerusalén (después de conquistar el reino de Nápoles). Unos años antes, un texto franciscano, el Opus Cristianissimum seu Davidicum, sostenía que la casa francesa, como descendiente del pueblo judio, tenía todo el derecho a reconquistar Jerusalén; vid. Christian de MERINDOL, L'imaginaire du pouvoir à la fin du Moyen Âge, "Représentation, pouvoir et royauté à la fin du Moyen Âge", París, 1995, pp. 73-74.
} 
propaganda, used to support the ro polky of hard authoritartsm and of territorial expansion. In this article are analyced different poctce compostions of prase caracter, and its propagandistic use. Is refered the relationship hetween propaganda and "royale entrancen, the relationship between propaganda and courteous party. the relation between liturgy and propaganda. the propagandiste value of the royal weddings and. to fiaish, are analyzed the war propaganda. 